[Agr. Biol. Chem., Vol. 35, No. 4, p. 485 490, 1971]

\title{
Utilization of Hydrocarbons by Microorganisms
}

\section{Part III. Effects of Organic Nutrients, Mineral Salts and Other Factors on the Accumulation of Vitamin $\mathrm{B}_{2}^{\dagger}$}

\author{
By Naomichi Nishio and Tadashi Kamikubo \\ Department of Fermentation Technology, Faculty of Engineering, \\ Hiroshima University, Sendamachi, Hiroshima \\ Received August 27, 1970
}

\begin{abstract}
The accumulation of vitamin $\mathrm{B}_{2}$ by Pichia guilliermondii Wickerham grown on hydrocarbon was investigated. Addition of the following materials stimulated vitamin $\mathrm{B}_{2}$ production: metal ions such as ferrous, cobalt, manganese, and calcium ions; organic nutrients such as yeast extract and casamino acid; amino acids such as proline and arginine; vitamins such as $B_{1}$, nicotinic acid, inositol, and $p$-aminobenzoic acid. Optimal aeration rate for vitamin $\mathrm{B}_{2}$ production was obtained in a $500-\mathrm{m}$ shaking flask containing $75 \mathrm{ml}$ of the medium.
\end{abstract}

It is well known that riboflavin is produced by microorganisms, especially Eremothecium ashbyii, ${ }^{1 \prime}$ Ashbya gossypii,, ${ }^{1,}$ Clostridium acetobutylicum, ${ }^{3,4)}$ Candida guilliermondii, ${ }^{5}$ Candida flareri, ${ }^{63}$ Mycocandida riboflavina, ${ }^{71}$ and Candida rubusta, and some of them are employed for commercial production of riboflavin.

Recently, it was reported that riboflavin could also be produced by several microorganisms such as Eremothecium ashbyii, ${ }^{9)}$ Pichia species $^{101}$ in hydrocarbon fermentation.

In the previous paper, ${ }^{11}$ it was reported that Pichia guilliermondii Wickerham isolated from soil produced much riboflavin in a

$\dagger$ Outline of this paper was reported at the Annual Meeting of the Agricultural Chemical Society of Japan, April, 1970. This study was partly supported by a grant from the Asahi Glass Foundation, Tokyo.

1) A. Guilliermond, M. Fontaine and A. Raffy, G. R. Acad. Sci. Paris, 201, 1077 (1935).

2) L. J. Wickerham, M. H. Flickinger and R. M. Johnston, Arch. Biochem., 9, 95 (1946).

3) I. Yamasaki and W. Yoshitome, Biochem. Z., 297, 398 (1938).

4) I. Yamasaki, ibid., 300, 160 (1939).

5) P. R. Burkholder, Proc. Natl. Acad. Sci. U.S., 29,166 (1938). hydrocarbon medium, and the effect of culture conditions on the growth of this yeast and its vitamin $\mathrm{B}_{2}$ production were also reported.

In this paper, a remarkable ability of Pichia guilliermondii Wickerham for vitamin $\mathrm{B}_{2}$ production, and the effect of various culture conditions on the growth and vitamin $B_{2}$ production are reported.

\section{MATERIALS AND METHODS}

Microorganism. The organism used in this study was Pichia guilliermondii Wickerham isolated from soil by the authors. This organism was maintained on hydrocarbon agar slant.

6) F. W. Tanner, C. Voinovich and J. M. Van Lanen, Science, 101, I80 (1945).

7) J. E. McClarey, U.S. Patent, 2, 537, 148 (1951).

8) S. Takao, Agr. Biol. Chem., 28, 559 (1964).

9) T. Sato, A. Maekawa, T. Suzuki and Y. Sahashi, Vitamins (Japan), 34, 542 (1966).

10) Y. Suzuki, T. Matsubayashi and T. Mochizuki, Abstract of papers, Annual Meeting of the Agricultural Chemical Society of Japan, p. 204 (1966).

11) N. Nishio and T. Kamikubo, J. Ferment. Technol., 48, 1 (1970). 
Cultivation methods. Cells, grown on hydrocarbonagar-slant at $30^{\circ} \mathrm{C}$ for 4 days, were inoculated into a test tube containing $10 \mathrm{ml}$ of medium (Table I), and then cultured on a shaker (190 strokes/min) at $27^{\circ} \mathrm{C}$ for 2 days. After centrifugation, the cells were suspended in sterilized water, and transmittance of the cell suspension was adjusted to approximately $14 \%$ at $670 \mathrm{~m} \mu$. Two $\mathrm{ml}$ of the suspension was inoculated into $100 \mathrm{ml}$ of medium in a $500 \mathrm{ml}$ shaking flask and cultured on a reciprocal shaker (115 strokes $/ \mathrm{min}$ ) at $27^{\circ} \mathrm{C}$.

Table I. Composition of Basal Medium Used

$\begin{array}{lcc}\text { Hydrocarbon (Paraffin mix.) } & 75 & \mathrm{~g} \\ \mathrm{NH}_{4} \mathrm{H}_{2} \mathrm{PO}_{4} & 3.75 \mathrm{~g} \\ \left(\mathrm{NH}_{4}\right)_{2} \mathrm{SO}_{4} & 3.75 \mathrm{~g} \\ \mathrm{KH}_{2} \mathrm{PO}_{4} & 2.5 \mathrm{~g} \\ \mathrm{~K}_{2} \mathrm{HPO}_{4} & 2.5 \mathrm{~g} \\ \mathrm{MgSO}_{4} \cdot 7 \mathrm{H}_{2} \mathrm{O} & 1.0 \mathrm{~g} \\ \text { Tween } 60 & 0.5 \mathrm{~g} \\ \text { Tap water } & 1,000 \mathrm{ml} \\ \mathrm{pH} & 6.5 & \end{array}$

Hydrocarbon. A hydrocarbon mixture containing n-undecane, $1.4 \%$; $n$-dodecane, $7.9 \% ; n$-tridecane, $47.8 \%$; and $n$-tetradecane, $40.8 \%$ by weight was supplied from Idemitsu Kosan Co. and used sole carbon source.

Hydrocarbon concentration in the culture medium was $7.50 .0(\mathrm{w} / \mathrm{v})$ unless otherwise stated.

Analysis. Riboflavin was estimated fluorophotometrically as described in the previous paper. Other analytical procedures were also as in the previous paper.

\section{RESULTS}

Effects of various factors on the growth and vitamin $\mathrm{B}_{2}$ production were examined.

\section{1) Metal ions}

Four kinds of metal ions in a form of sulfate hydride were tested. The results obtained after 10 day culture are shown in Table II. Ferrous ion seems to be neccesary for the better growth and somewhat effective for promoting riboflavin production at con-
Table II. EFfect of Metal Ions on the Growth and Vitamin $B_{2}$ Production

\begin{tabular}{|c|c|c|c|c|}
\hline \multirow[b]{2}{*}{ Metal ions } & \multirow{2}{*}{$\begin{array}{c}\text { Amt. } \\
\text { added } \\
\text { ( } \mu \mathrm{g} / \text { liter) }\end{array}$} & \multirow{2}{*}{$\begin{array}{c}\text { Cell yield } \\
\text { (g dry } \\
\text { wt./liter) }\end{array}$} & \multicolumn{2}{|c|}{ Vit. $B_{2}$ produced in } \\
\hline & & & $\begin{array}{c}\text { Super- } \\
\text { natant } \\
\text { (mg/liter) }\end{array}$ & $\begin{array}{c}\text { Cells } \\
(\mu \mathrm{g} / \mathrm{g} \text { dry } \\
\text { cells) }\end{array}$ \\
\hline $\begin{array}{c}\mathrm{Fe}^{2+} \\
\left(\mathrm{FeSO}_{4}\right. \\
\left.\cdot 7 \mathrm{H}_{2} \mathrm{O}\right)\end{array}$ & $\left\{\begin{array}{c}2000 \\
200 \\
20 \\
2 \\
0.2\end{array}\right.$ & $\begin{array}{l}6.17 \\
6.55 \\
4.41 \\
4.10 \\
4.18\end{array}$ & $\begin{array}{r}1.6 \\
83.3 \\
93.3 \\
88.4 \\
64.0\end{array}$ & $\begin{array}{r}2 \\
8 \\
69 \\
60 \\
31\end{array}$ \\
\hline $\begin{array}{c}\mathrm{Co}^{2+} \\
\left(\mathrm{CoSO}_{4}\right. \\
\left.\cdot 7 \mathrm{H}_{2} \mathrm{O}\right)\end{array}$ & $\left\{\begin{array}{r}10000 \\
1000 \\
100 \\
10\end{array}\right.$ & $\begin{array}{l}2.46 \\
3.78 \\
6.61 \\
4.36\end{array}$ & $\begin{array}{r}81.8 \\
117.3 \\
123.8 \\
57.4\end{array}$ & $\begin{array}{r}268 \\
95 \\
148 \\
89\end{array}$ \\
\hline $\begin{array}{c}\mathrm{Mn}^{2+} \\
\left(\mathrm{MnSO}_{4}\right. \\
\left..4 \mathrm{H}_{2} \mathrm{O}\right)\end{array}$ & $\left\{\begin{array}{r}20000 \\
2000 \\
200 \\
20\end{array}\right.$ & $\begin{array}{l}4.83 \\
4.11 \\
6.36 \\
4.26\end{array}$ & $\begin{array}{r}58.2 \\
84.2 \\
125.6 \\
120.0\end{array}$ & $\begin{array}{r}9 \\
12 \\
14 \\
96\end{array}$ \\
\hline $\begin{array}{c}\mathrm{Ca}^{2+} \\
\left(\mathrm{CaSO}_{4}\right. \\
\left.\cdot 2 \mathrm{H}_{2} \mathrm{O}\right)\end{array}$ & $\left\{\begin{array}{r}50000 \\
5000 \\
500 \\
50\end{array}\right.$ & $\begin{array}{l}5.35 \\
5.20 \\
3.39 \\
3.78\end{array}$ & $\begin{array}{r}151.0 \\
148.4 \\
67.8 \\
72.8\end{array}$ & $\begin{array}{r}18 \\
49 \\
103 \\
97\end{array}$ \\
\hline Blank $A^{a l}$ & - & 6.71 & 192.0 & 16 \\
\hline Blank $B^{b l}$ & - & 6.21 & 57.0 & 16 \\
\hline
\end{tabular}

Cultivation was carried out on a reciprocal shaker for 10 days at $27^{\circ} \mathrm{C}$.

a) Tap water was used in $\mathrm{A}$.

b) Deionized water was used in $B$.

The conc. of hydrocarbon was $3.75 \%(\mathrm{w} / \mathrm{v})$.

centration of $2 \sim 200 \mu \mathrm{g}$ per liter, but the addition of iron at $2 \mathrm{mg}$ per liter gave an inhibitory effect on riboflavin production. Cobalt, manganese, and calcium ions stimulated the vitamin production and their optimal concentrations were $0.1,0.2,50 \mathrm{mg}$ per liter, respectively. However, in each case, the vitamin production was lower than in Blank $A$, in which tap water was used in stead of deionized water.

\section{2) Organic nutrients}

Since the composition of medium used in these studies was simple, it was expected that a certain organic substance would have a good effect on the growth of yeast as well as vitamin $\mathbf{B}_{2}$ production. As shown in Table III, $0.05 \sim 0.1 \%$ of yeast extract and casamino acid stimulated the vitamin production, but 
TABLE III. EFFEct OF ORganic NUTRIENTS ON the Growth and Vitamin $B_{2}$ Production

\begin{tabular}{|c|c|c|c|c|}
\hline \multirow[b]{2}{*}{$\begin{array}{l}\text { Organic } \\
\text { nutrients }\end{array}$} & \multirow{2}{*}{$\begin{array}{l}\text { Amt. } \\
\text { added } \\
\text { (g/liter) }\end{array}$} & \multirow{2}{*}{$\begin{array}{c}\text { Cell yield } \\
\text { (g dry } \\
\text { wt./liter) }\end{array}$} & \multicolumn{2}{|c|}{ Vit. $B_{2}$ produced in } \\
\hline & & & $\begin{array}{l}\text { Super- } \\
\text { natant } \\
\text { (mg/liter) }\end{array}$ & $\begin{array}{c}\text { Cells } \\
(\mu \mathrm{g} / \mathrm{g} \text { dry } \\
\text { cells })\end{array}$ \\
\hline $\begin{array}{l}\text { Yeast } \\
\text { extract }\end{array}$ & $\left\{\begin{array}{l}0.1 \\
0.5 \\
1.0\end{array}\right.$ & $\begin{array}{l}7.58 \\
7.89 \\
8.10\end{array}$ & $\begin{array}{l}114.9 \\
187.0 \\
200.0\end{array}$ & $\begin{array}{r}42 \\
33 \\
9\end{array}$ \\
\hline $\begin{array}{l}\text { Casamino } \\
\text { acid }\end{array}$ & $\left\{\begin{array}{l}0.1 \\
0.5 \\
1.0\end{array}\right.$ & $\begin{array}{l}7.66 \\
7.57 \\
7.29\end{array}$ & $\begin{array}{l}105.0 \\
252.0 \\
280.5\end{array}$ & $\begin{array}{l}11 \\
18 \\
51\end{array}$ \\
\hline $\begin{array}{l}\text { Poly } \\
\text { peptone }\end{array}$ & $\left\{\begin{array}{l}0.1 \\
0.5 \\
1.0\end{array}\right.$ & $\begin{array}{l}7.41 \\
8.46 \\
8.63\end{array}$ & $\begin{array}{r}91.0 \\
172.6 \\
80.0\end{array}$ & $\begin{array}{r}15 \\
12 \\
9\end{array}$ \\
\hline $\begin{array}{l}\text { Malt } \\
\text { extract }\end{array}$ & $\left\{\begin{array}{l}0.1 \\
0.5 \\
1.0\end{array}\right.$ & $\begin{array}{l}7.10 \\
7.41 \\
7.38\end{array}$ & $\begin{array}{r}86.7 \\
84.0 \\
105.0\end{array}$ & $\begin{array}{r}5 \\
16 \\
11\end{array}$ \\
\hline $\begin{array}{l}\text { Meat } \\
\text { extract }\end{array}$ & $\left\{\begin{array}{l}0.01 \\
0.1\end{array}\right.$ & $\begin{array}{l}7.64 \\
7.74\end{array}$ & $\begin{array}{l}103.2 \\
126.0\end{array}$ & $\begin{array}{r}18 \\
8\end{array}$ \\
\hline None & - & 7.14 & 150.0 & 109 \\
\hline
\end{tabular}

Cultivation was carried out on a reciprocal shaker for 10 days at $27^{\circ} \mathrm{C}$.

The conc. of hydrocarbon was $3.75 \%(\mathrm{w} / \mathrm{v})$.

other organic nutrients showed no effect on the vitamin production, although these stimulated the growth of yeast.

\section{3) Amino acids}

Since yeast extract and casamino acid showed some stimulating effect on the vitamin production as mentioned above, the effect of some organic substances on the production of vitamin $B_{2}$ was investigated. In this study, various amino acids were added to the medium at a relatively low concentration ( $1 \mathrm{mmole}$ (liter). As shown in Table IV, arginine and proline slightly stimulated the vitamin production.

\section{4) Vitamins}

Among eight water-soluble vitamins tested, $\mathrm{B}_{1}$, nicotinic acid, inositol, and $p$-aminobenzoic acid showed a good effect on vitamin $\mathrm{B}_{2}$ production by $P i$. guilliermondii, as shown in Table $\mathrm{V}$, whereas vitamin $\mathrm{B}_{6}$, biotin, pantothenic acid, and folic acid were ineffective.
TABLE IV. EFFECT OF AMINO ACIDS ON THE Growth and Vitamin $B_{2}$ Production

\begin{tabular}{|c|c|c|c|}
\hline \multirow[b]{2}{*}{ Amino acid } & \multirow{2}{*}{$\begin{array}{c}\text { Cell yield } \\
\text { (g dry } \\
\text { wt./liter) }\end{array}$} & \multicolumn{2}{|c|}{ Vit. $B_{2}$ produced in } \\
\hline & & $\begin{array}{l}\text { Super- } \\
\text { natant } \\
\text { (mg/liter) }\end{array}$ & $\begin{array}{c}\text { Cells } \\
(\mu \mathrm{g} / \mathrm{g} \mathrm{d} r y \\
\text { cells })\end{array}$ \\
\hline L-Glycine & 7.00 & 33.9 & 28 \\
\hline L-Leucine & 6.86 & 62.4 & 20 \\
\hline D,L-Isoleucine & 6.71 & 125.8 & 40 \\
\hline L-Cystein & 6.02 & 118.0 & 22 \\
\hline L-Cystine & 6.05 & 38.5 & 12 \\
\hline D,L-Methionine & 7.07 & 180.1 & 17 \\
\hline L-Tyrosine & 6.68 & 84.1 & 10 \\
\hline $\mathrm{L}$-Arginine $\cdot \mathrm{HCl}$ & 6.12 & 247.2 & 60 \\
\hline $\mathrm{L}$-Histidine $\cdot \mathrm{HCl} \cdot \mathrm{H}_{2} \mathrm{O}$ & 6.02 & 79.5 & 65 \\
\hline L-Hydroxyproline & 6.45 & 222.2 & 14 \\
\hline D,L-Tryptophan & 6.17 & 76.2 & 29 \\
\hline L-Glutamic acid & 7.01 & 73.8 & 14 \\
\hline L-Asparagine & 7.60 & 48.7 & 13 \\
\hline D,L-Alanine & 6.57 & 171.9 & 49 \\
\hline $\mathrm{D}, \mathrm{L}$-Valine & 6.31 & 145.2 & 48 \\
\hline None & 6.42 & 213.9 & 53 \\
\hline
\end{tabular}

Cultivation was carried out on a reciprocal shaker for 10 days at $27^{\circ} \mathrm{C}$.

Each amino acid was added at 1 mmole/liter.

The conc. of hydrocarbon was $3.75 \%(\mathrm{w} / \mathrm{v})$.

Table V. EFfect of Water SOluble Vitamins on the Growth and Vitamin B $B_{2}$ Production

\begin{tabular}{lrrrr} 
Vitamin & $\begin{array}{c}\text { Amt. } \\
\text { added } \\
(\mu \mathrm{g} / \text { liter })\end{array}$ & $\begin{array}{c}\text { Cell yield } \\
\text { (g dry } \\
\text { wt./liter) }\end{array}$ & $\begin{array}{c}\text { Vit. } \\
\text { Super- } \\
\text { natant } \\
(\mathrm{mg} / \mathrm{liter})\end{array}$ & $\begin{array}{c}\text { Cells } \\
(\mu \mathrm{g} / \mathrm{g} \text { dry } \\
\text { cells })\end{array}$ \\
\hline Vitamin $\mathrm{B}_{1}$ & 50 & 5.82 & 200.0 & 17 \\
Vitamin $\mathrm{B}_{6}$ & 50 & 7.33 & 130.0 & 39 \\
Nicotinic acid & 50 & 6.79 & 174.2 & 54 \\
Biotin & 1 & 7.27 & 133.3 & 17 \\
Ca-pantothenate & 50 & 7.12 & 111.1 & 10 \\
PABA & 50 & 6.74 & 158.2 & 16 \\
Folic acid & 1 & 7.24 & 112.5 & 18 \\
Inositol & 5000 & 7.36 & 167.9 & 47 \\
All factors & & 6.57 & 170.1 & 40 \\
None & - & 6.77 & 117.3 & 36 \\
\hline
\end{tabular}

Cultivation was carried out on a reciprocal shaker for 10 days at $27^{\circ} \mathrm{C}$.

The conc. of hydrocarbon was $3.75 \%(\mathrm{w} / \mathrm{v})$. 
Table VI. Effect of Inorganic Salts on the Growth and Vitamin B 2 Production

\begin{tabular}{|c|c|c|c|c|c|c|}
\hline \multirow[b]{2}{*}{$\mathrm{KH}_{2} \mathrm{PO}_{4}$} & \multicolumn{2}{|c|}{ Inorganic salts } & \multirow{3}{*}{$\mathrm{NaH}_{2} \mathrm{PO}_{4}$} & \multirow{3}{*}{$\begin{array}{c}\text { Cell yield } \\
\text { (g dry } \\
\text { wt./liter) }\end{array}$} & \multicolumn{2}{|c|}{ Vit. $B_{2}$ produced in } \\
\hline & $\mathrm{K}_{2} \mathrm{HPO}_{4}$ & $\mathrm{Na}_{2} \mathrm{HPO}_{4}$ & & & \multirow{2}{*}{$\begin{array}{l}\text { Supernatant } \\
(\mathrm{mg} / \text { liter })\end{array}$} & \multirow{2}{*}{$\begin{array}{c}\text { Cells } \\
(\mu \mathrm{g} / \mathrm{g} \mathrm{dry} \\
\text { cells })\end{array}$} \\
\hline & Amounts 0 & led ( $g /$ liter) & & & & \\
\hline 2.5 & - & - & - & 7.72 & 123.5 & 18 \\
\hline 5.0 & - & - & - & 9.44 & 160.4 & 40 \\
\hline- & 2.5 & - & - & 7.83 & 118.0 & 43 \\
\hline- & 5.0 & - & - & 8.70 & 202.8 & 67 \\
\hline- & - & 2.5 & - & 0.98 & 0.2 & 112 \\
\hline - & - & 5.0 & - & 0.99 & 0.1 & 111 \\
\hline- & - & - & 2.5 & 1.19 & 0.2 & 294 \\
\hline- & - & - & 5.0 & 1.23 & 0.2 & 400 \\
\hline 2.5 & 2.5 & - & - & 9.51 & 171.4 & 7 \\
\hline 4.0 & 1.0 & - & - & 9.19 & 105.6 & 46 \\
\hline 1.0 & 4.0 & - & - & 9.04 & 162.2 & 44 \\
\hline 2.5 & - & 2.5 & - & 8.62 & 82.6 & 8 \\
\hline 4.0 & - & 1.0 & - & 9.41 & 152.0 & 74 \\
\hline 1.0 & - & 4.0 & - & 7.75 & 111.1 & 14 \\
\hline- & 2.5 & 2.5 & - & 7.69 & 17.7 & 8 \\
\hline- & 4.0 & 1.0 & - & 9.10 & 159.2 & 25 \\
\hline- & 1.0 & 4.0 & - & 7.16 & 131.3 & 22 \\
\hline
\end{tabular}

Cultivation was carried out on a reciprocal shaker for 10 days at $27^{\circ} \mathrm{C}$.

\section{5) Inorganic salts}

Four kinds of salts were tested to see if there might be the influence of buffer action of $\mathrm{pH}$ due to inorganic salts in the medium on vitamin $B_{2}$ production. As shown in Table VI, maximal vitamin $B_{2}$ production was obtained when dipotassium hydrophosphate was added at the concentration of $5 \mathrm{~g}$ per liter.

\section{6) Substances related to nucleic acids}

It is suggested that a large amount of the vitamin production is concerned with abnormality of nucleic acid metabolism. Therefore, it was expected that addition of a purine base would stimulate vitamin $\mathrm{B}_{2}$ production. The results are shown in Table VII. Addition of $20 \mathrm{mg}$ per liter of every substance tested, especially inosine, stimulated the vitamin production.

\section{7) Aeration}

In hydrocarbon fermentation, aeration is an
TABLE VII. EFFECT OF PURINES ON THE GRowTH and Vitamin $B_{2}$ Production

\begin{tabular}{|c|c|c|c|c|}
\hline \multirow[b]{2}{*}{ Purines } & \multirow{2}{*}{$\begin{array}{c}\text { Amt. } \\
\text { added } \\
\text { (mg/liter) }\end{array}$} & \multirow{2}{*}{$\begin{array}{c}\text { Cell yield } \\
\text { (g dry } \\
\text { wt./liter) }\end{array}$} & \multicolumn{2}{|c|}{ Vit. $B_{2}$ produced in } \\
\hline & & & $\begin{array}{c}\text { Super- } \\
\text { natant } \\
\text { (mg/liter) }\end{array}$ & $\begin{array}{c}\text { Cells } \\
(\mu \mathrm{g} / \mathrm{g} \text { dry } \\
\text { cells })\end{array}$ \\
\hline Adenine & $\begin{array}{r}5 \\
20 \\
50\end{array}$ & $\begin{array}{l}9.05 \\
8.60 \\
8.86\end{array}$ & $\begin{array}{l}140.3 \\
154.1 \\
137.5\end{array}$ & $\begin{array}{l}25 \\
40 \\
56\end{array}$ \\
\hline Xanthine & $\begin{array}{r}5 \\
20 \\
50\end{array}$ & $\begin{array}{l}9.20 \\
8.18 \\
8.61\end{array}$ & $\begin{array}{l}128.4 \\
153.8 \\
137.1\end{array}$ & $\begin{array}{l}50 \\
45 \\
50\end{array}$ \\
\hline Inosine & $\begin{array}{r}5 \\
20 \\
50\end{array}$ & $\begin{array}{l}9.03 \\
7.69 \\
9.21\end{array}$ & $\begin{array}{l}186.7 \\
246.8 \\
180.4\end{array}$ & $\begin{array}{l}45 \\
42 \\
34\end{array}$ \\
\hline None & - & 8.73 & 142.8 & 35 \\
\hline
\end{tabular}

Cultivation was carried out on a reciprocal shaker for 10 days at $27^{\circ} \mathrm{C}$.

The conc. of hydrocarbon was $3.75 \%(w / v)$.

important factor for microbial growth as well as emulsification of the substrate. Growth and vitamin $B_{2}$ synthesis were also affected by aeration, as shown in Table VIII. 
TABle VIII. RElationship BeTweEN OXYGeN SUPPly and Vitamin $B_{2}$ Production

\begin{tabular}{rrrrr}
$\begin{array}{c}\text { Amt. of } \\
\text { medium } \\
\text { in } 500 \mathrm{ml} \\
\text { flask }(\mathrm{ml})\end{array}$ & $\begin{array}{c}K d \\
\left(\times 10^{-6}\right)\end{array}$ & $\begin{array}{c}\text { Cell yield } \\
(\mathrm{g} \text { dry } \\
\text { wt./liter })\end{array}$ & $\begin{array}{c}\text { Super- } \\
\text { natant } \\
(\mathrm{mg} / \mathrm{liter})\end{array}$ & $\begin{array}{c}\text { Cells } \\
(\mu \mathrm{g} / \mathrm{g} \text { dry } \\
\text { cells })\end{array}$ \\
\hline 25 & 11.0 & 7.28 & 132.6 & 12 \\
50 & 8.4 & 8.01 & 132.0 & 23 \\
75 & 6.5 & 7.22 & 223.3 & 53 \\
100 & 4.7 & 8.43 & 166.3 & 38 \\
125 & 3.4 & 8.06 & 15.8 & 27,698 \\
150 & 3.0 & 4.31 & 10.9 & 29,510
\end{tabular}

Cultivation was carried out on a reciprocal shaker for 10 days at $27^{\circ} \mathrm{C}$.

Vitamin $B_{2}$ content in the supernatant fraction was maximal in the case of a $500-\mathrm{ml}$ flask containing $75 \mathrm{ml}$ of the medium, and it extremely decreased when the volume of medium was more than $100 \mathrm{ml}$ although the vitamin per cell was remarkably increased.

8) Relationship between dry cell weight and the concentration of growing cells

Concentrations of growing cells indicated as unit of optical density (abbreviated as UOD) was determined as follows: optical density of the cell suspension was adjusted to approximately 0.3 at $570 \mathrm{~m} \mu$ by diluting

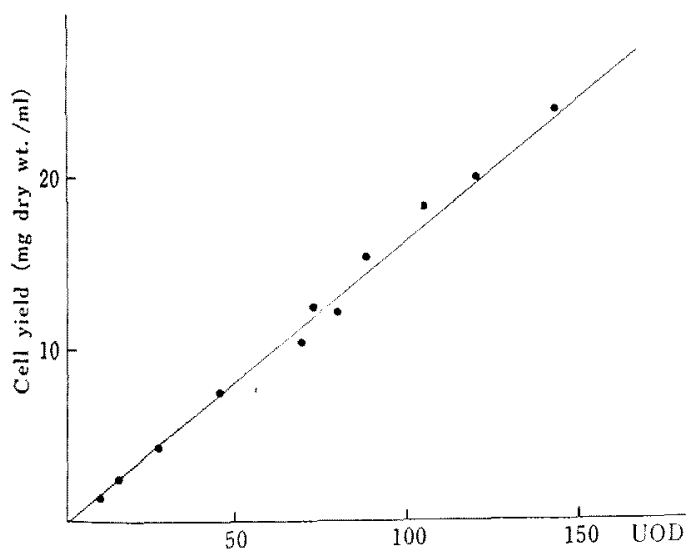

FIG. 1. Relationship between Dry Cell Weight and Cell Concentration. with water. Subsequently, UOD was determined by the product of diluted volume and OD. As shown in Fig. 1, a linear relation was obtained between cell yield and UOD of the culture.

\section{9) pH control}

Figure 2 shows the time course of vitamin $\mathrm{B}_{2}$ production and the growth of yeast. Since $\mathrm{pH}$ of the culture broth lowered in the log phase, it was adjusted to 6.5 with sodium hydroxide. As shown in Fig. 3, when $\mathrm{pH}$ of the broth was adjusted to 6.5, the growth of yeast was extremely increased, while vitamin $B_{2}$ production was decreased.

\section{DISCUSSION}

Some flavinogenic microorganisms are wellknown to be strongly inhibited in respect to

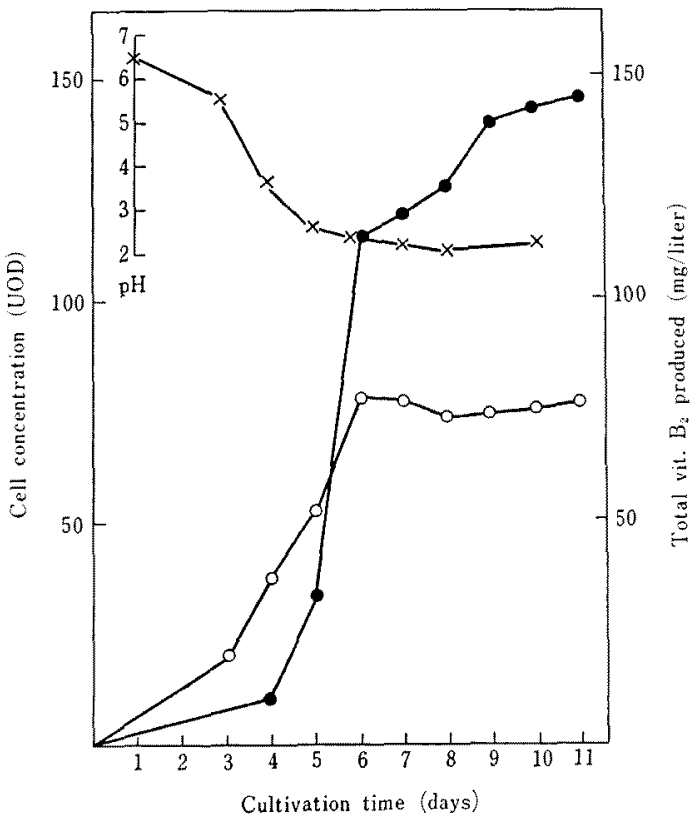

FIG. 2. Time Course of Vitamin $B_{2}$ Production and the Growth of Yeast.

- - Total vit. $\mathrm{B}_{2}$ produced; $\mathrm{O}-\mathrm{O}$, Cell concentration; $x-\times, \mathrm{pH}$ of broth. 


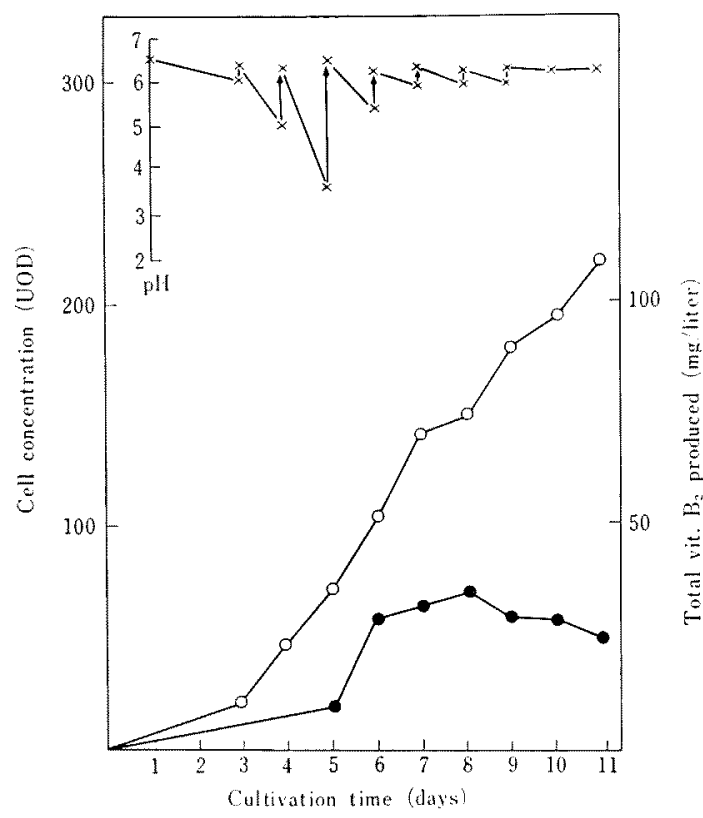

FIG. 3. Effect of pH Control on the Growth and Vitamin $\mathrm{B}_{2}$ Production.

- Total vit. $\mathrm{B}_{2}$ produced; $\mathrm{O}-\mathrm{O}$, Cell concentration; $x-\times, \mathrm{pH}$ of broth; $\uparrow \cdot \mathrm{pH}$ was adjusted at each time with $30,0 \mathrm{NaOH}$.

riboflavin production when iron is present in the media; for example, two genera, Clostridium and Candida, are quite sensitive to this metal. In hydrocarbon fermentation by Pichia guilliermondii Wickerham, it was observed that riboflavin production was sharply reduced with increasing concentration of iron.

In hydrocarbon fermentation, aeration is an important factor for the microbial growth as well as emulsification of the substrate. Growth and vitamin $B_{2}$ synthesis of $P i$. guilliermondii Wickerham were also affected by aeration as shown in Table VIII. Vitamin $\mathrm{B}_{2}$ content in the supernatant fraction was maximal in the case of a $500-\mathrm{ml}$ flask containing $75 \mathrm{ml}$ of the medium and extremely decreased when the volume of medium was more than $100 \mathrm{ml}$, although the vitamin per cell was extremely increased in the latter case. Probably, when the volume of medium was increased, the growth of yeast was so slow that almost all vitamin $B_{2}$ kept in the cells during 8 day culture.

$\mathrm{pH}$ of the culture broth became lower in the $\log$ phase, and adjusting $\mathrm{pH}$ to 6.5 increased the growth of yeast. Yeast could be grown at relatively low $\mathrm{pH}$ as compared with bacteria, but at an extremely low $\mathrm{pH}$, the growth activity of the yeast must be reduced. The adjustment of $\mathrm{pH}$ to 6.5 , however, significantly decreased vitamin $\mathrm{B}_{2}$ production in hydrocarbon fermentation by $P i$. guilliermondii Wickerham.

Acknowledgement. The authors wish to express their hearty thanks to Idemitsu Kosan Co. for their generous gift of hydrocarbon samples. 